\title{
Family, Social, and Health Worker Support of Complience Behaviour to Patients with Hypertension In Bogor, Indonesia
}

\section{Siska Maytasari ${ }^{1)}$, Ratu Ayu Dewi Sartika ${ }^{2)}$}

1 Health Service Quality Study Group, Public Health Faculty, Universitas Indonesia, Depok, Indonesia

2 Department of Public Health Nutrition, Public Health Faculty, Universitas Indonesia, Depok, Indonesia

Email: siska.maytasari45@gmail.com

\begin{abstract}
Background: Abnormalities of the heart and blood vessels were marked by an increase in blood pressure are known as hypertension. Worldwide, high blood pressure is estimated to affect more than one in three adults aged 25 years and over, or about one billion people. Overall, high-income countries have a lower prevalence of hypertension (35\% of adults) than low and middle-income groups (40\% of adults). The prevalence of hypertension in Indonesia based on the Basic Health Research (Riskesdas) data in 2018 was 34.1\%. Objective: This study determines the relationship of family support, social support, and health worker support with compliance of patients with hypertension. Methods: This research was conducted at the Tegal Gundil Community Health Center, North Bogor District, Bogor City, Indonesia, which was conducted from May to December 2017. The design of this study was cross-sectional. Sampling was carried out with a purposive sampling method with inclusion and exclusion criteria. The former consisted of all patients with hypertension aged 25-65 years who routinely control during the last six months who are present and willing to be interviewed during the study. The later includes patients with hypertension who have memory disorders with the number of samples of 110 respondents. Results: The results showed the respondents were dominated by the age of under 59 (75.5\%), female (86.4\%), junior high school as the highest education (68.2\%), have no job (81.8\%), and the prevalence of their sufferers' compliance was $47.3 \%$. The results of the Chi-square test showed that family support, social environment, and health workers were associated with compliance in patients with hypertension $(O R=2.461 ; \mathrm{Cl} 95 \% 1.140$ to 5.310; $P$ Value $=0.034)$. Conclusion: In order to improve compliance of patients with hypertension, it is necessary to pursue a program of activities focused on health promotion activities not only for patients but also involving family and social members.
\end{abstract}

Keywords: Family, Health Workers, Hypertension, Social, Support.

\section{INTRODUCTION}

Hypertension is abnormalities of the heart and blood vessels that are marked by an increase in blood pressure (WHO, 2013). If the measurement results are twice with a distance of 5 minutes and inadequate rest conditions, the results of blood pressure of more than $140 / 90 \mathrm{mmHg}$ are declared hypertension (Kementerian Kesehatan Republik Indonesia, 2014). In 2017, the American Heart Association (AHA) and the American College of Cardiology (ACC) issued the latest hypertension guidelines. This guideline contains many significant changes in the management of hypertension. One of the biggest jumps in this guideline is a change in classification or even the definition of hypertension. In the hypertension guidelines, hypertension is determined when systolic blood pressure $\geq 130 \mathrm{mmHg}$ or diastolic blood pressure $\geq 80 \mathrm{mmHg}$ (Whelton et al., 2018).

Every year, hypertension is the number one cause of death in the world because hypertension is one of the entry points or risk factors for diseases such as stroke, heart disease, diabetes, kidney failure (Kemenkes RI, 2019). According to the WHO data showed one in three adults aged 25 years and over experience high blood pressure worldwide, or around 
1.13 billion people who suffer from hypertension. Low and middle-income countries have a higher prevalence $(40 \%$ of adults) compared to high-income countries (35\% of adults) (WHO, 2013), and $80 \%$ of adults with diabetes mellitus have hypertension (CDC, 2013). The main modifiable risk factor for cardiovascular disease (CVD) and premature death in the United States and around the world is hypertension (Forouzanfar et al., 2016; Mills et al., 2016). A positive and robust relationship between blood pressure (BP) and CVD risk and mortality has been proven in observational studies (Wei et al., 2017).

According to the 2017 International Health Metrics Monitoring and Evaluation (IHME) data in Indonesia, the first cause of death is caused by stroke, followed by ischemic heart disease, diabetes, tuberculosis, cirrhosis, diarrhea, Alzheimer, lower respiratory tract infections, and disorders neonatal and traffic accidents. Data from the Health Insurance Administering Agency (BPJS) states that the cost of hypertension services has increased every year, namely in 2016 amounting to 2.8 trillion rupiahs, in 2017 and 2018, amounted to 3 trillion rupiahs. The prevalence of hypertension in Indonesia based on the results of blood pressure measurement in population $\geq 18$ years by province based on Basic Health Research (Riskesdas) data in 2018 is $34.1 \%$, the highest in South Kalimantan (44.1\%), while the lowest in Papua is (22.2\%).

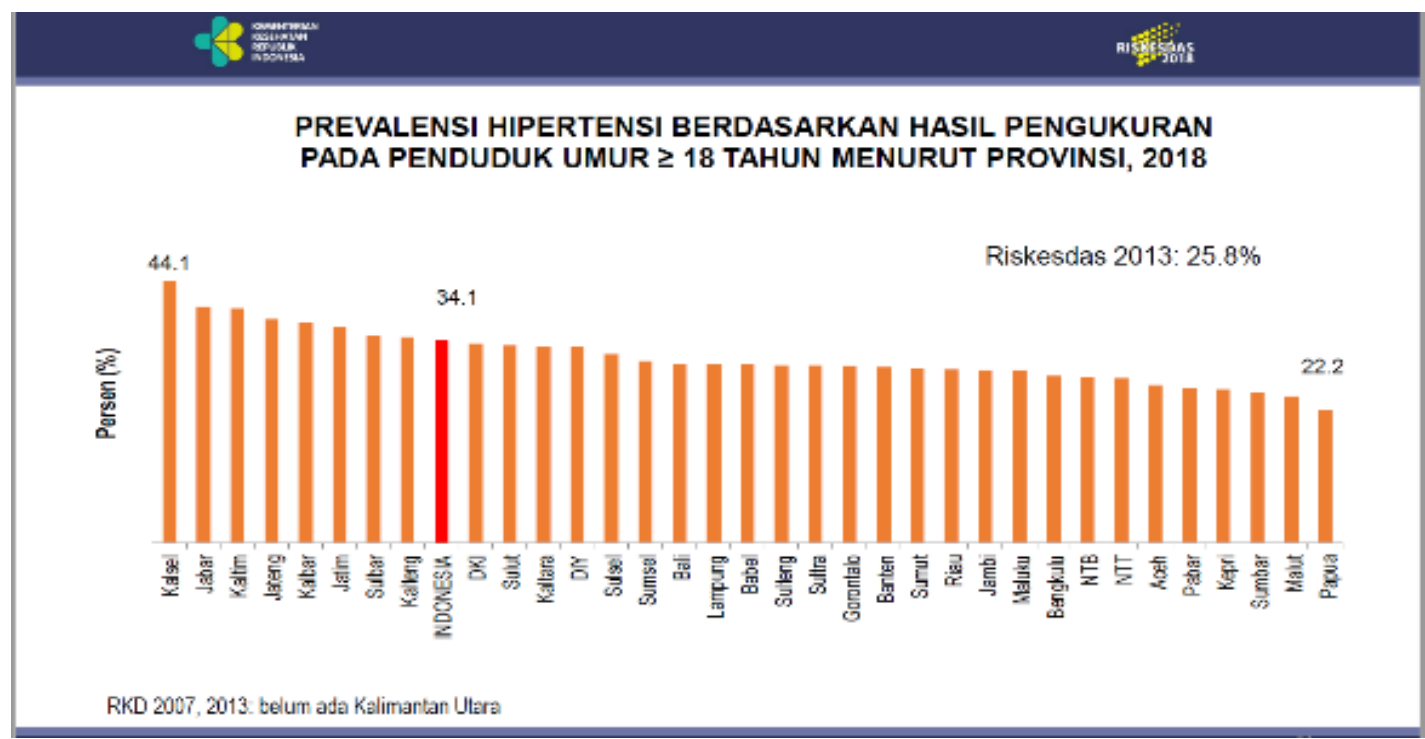

Source: Kementerian Kesehatan Republik Indonesia, 2019

Figure 1. Prevalence of Hypertension in the Population Aged $\geq 18$ Years Based on Province

From the prevalence of hypertension of $34.1 \%$, it is known that as much as $8.8 \%$ were diagnosed with hypertension and $13.3 \%$ of people diagnosed with hypertension did not take medication, and $32.3 \%$ did not take medication regularly. It shows that the majority of hypertension sufferers do not know that they are hypertension and, therefore, do not get treatment. The reasons for hypertension sufferers that did not take medication are because hypertension sufferers feel healthy (59.8\%), irregular visits to health facilities $(31.3 \%)$, taking traditional medicine $(14.5 \%)$, using other therapies $(12.5 \%)$, forgot to take medicine $(11.5 \%)$, unable to buy medicine $(8.1 \%)$, there were side effects of the drug (4.5\%), and hypertension medication was not available in health care facilities (2\%) (Kementerian Kesehatan Republik Indonesia, 2019a).

The prevalence of hypertension in Bogor City in 2017 is $22.07 \%$, and it is number two in the top ten diseases in public health centers. The main contributors to poor hypertension control and the main obstacles to reducing CVD deaths are that patients do not follow recommended medical or health advice, including failure to survive with drugs and make lifestyle modifications that are suggested. Only about $20 \%$ of patients with hypertension followed their treatment plan well enough to improve, and Up to $25 \%$ of patients do not fulfill their initial prescription for 
antihypertensive therapy. During the first year of treatment, the average patient had antihypertensive drugs, only $50 \%$ of the time, and only 1 in 5 patients had adherence high enough to achieve the benefits observed in clinical trials. Many factors contribute to poor compliance. So as a solution, there need to be efforts to improve compliance at the patient, provider, and health care system level (Whelton et al., 2018). The objectives of this study were to determine the relationship between family support, social support, and health workers' support with compliance of patients with hypertension.

\section{METHOD}

The study was hospitality based and conducted at the Tegal Gundil Community Health Center, North Bogor District, Bogor City, Indonesia, which was conducted from May to December 2017. The design of this study was crosssectional. The target population is all adult hypertension sufferers, male and female in physical and mental health, aged 25-65 years in the community health-center work area. The population of this study was patients diagnosed with hypertension and routine treatment and control for the last 6 (six) months at the Tegal Gundil community health center. It was done to get a sample of people who suffered from hypertension, based on the population which was the study sample, sampling was carried out with purposive sampling method, with Inclusion criteria namely all patients with hypertension aged 25-65 years who routinely control during the last six months who are present and willing to be interviewed during the study, exclusion criteria namely patients with hypertension who have memory disorders. Subjects for this study were selected from a list of a known hypertensive subject; the number of samples in this study was 110 respondents.

$$
\begin{aligned}
& \text { After obtaining informed } \\
& \text { consent, the respondent was }
\end{aligned}
$$
questionnaire that had several issues, including collected blood pressure data (in this study, hypertension was defined as a systolic BP of $140 \mathrm{mmHg}$ or higher or a diastolic BP of $90 \mathrm{mmHg}$ or higher), food intake, physical activity, knowledge, attitude, Perception of perceived benefits, Perception of the perceived barrier, Perception about selfefficacy, family support, social support and health workers, medication adherence, dietary compliance, stress levels, cigarette consumption, compliance with routine blood pressure checks, and routine weight weighing compliance and Semi-Quantitative Food Frequency Questionnaire (SFFQ).

The research instrument used in data collection was a questionnaire. Family support, Social support, and health workers support were assessed in the questionnaire using the question (1) As long as you suffer from hypertension, which gives the motivation and motivation to live a healthy lifestyle in applying diet and taking medicine (2) Be reminded to take medicine (3) Warn to avoid prohibited foods/drinks (4) Invited to exercise regularly (5) Participate in a hypertensive diet (participate in consuming low-salt foods) (6) Remind to check blood pressure and consult a diet regularly (7) Helps manage stress (8) Always remind to stop smoking (9) Remind to weigh regularly. Compliance was defined using the 13 questions on the questionnaire patient compliance consisting of medication, dietary compliance, non-smoking adherence, compliance with physical activity, compliance with routine blood pressure checks, and routine weight checks. The use of compliance as a variable was defined as compliant (where the respondent answers $\geq$ seven questions). Researchers used secondary data. Data were analyzed by univariate analysis and bivariate analysis using the chi-square test.

\section{RESULTS AND DISCUSSION}

Based on Table 1, it is described that the largest percentage of each variable is as follows: $75.5 \%$ age of respondents is $<59$ years, $86.4 \%$ of respondents' gender is female, $68.2 \%$ of respondents with the latest education $\leq$ Junior High School, $81.8 \%$ of respondents did not work, $52.7 \%$ of respondents had low knowledge and $60 \%$ had negative attitudes. $84.5 \%$ felt perceived benefits were good, $51.8 \%$ felt perceived obstacles perceived good, $83.6 \%$ felt good perception of self-efficacy, $52 \%$ felt 
family support, social environment, and health workers support were good enough, and $52.7 \%$ of respondents were not compliant.

Table1. Demographic characteristics, knowledge, attitude, Perception, support, and compliance of respondents

\begin{tabular}{lcc}
\hline \multicolumn{1}{c}{ Variables } & $\mathbf{n}$ & $\%$ \\
\hline Age & & \\
\hline$<44$ year & 22 & 20 \\
$\geq 45$ year & 88 & 80 \\
\hline Sex & & \\
\hline Male & 15 & 13.6 \\
Female & 95 & 86.4 \\
\hline Level of education & & \\
\hline S Junior high school & 75 & 68.2 \\
$>$ Junior high school & 35 & 31.8 \\
\hline Job & & \\
\hline Unemployed & 90 & 81.8 \\
Employed & 20 & 18.2 \\
\hline Knowledge & & \\
\hline Not Sufficient & 58 & 52.7 \\
Sufficient & 52 & 47.3 \\
\hline Attitude & & \\
\hline Negative & 66 & 60 \\
Positive & 44 & 40 \\
\hline Perception of perceived ben &
\end{tabular}

\begin{tabular}{lcc}
\hline Perception of perceived benefits & \\
\hline Not good & 17 & 15.5
\end{tabular}

Good $93 \quad 84.5$

\begin{tabular}{lcc}
\hline \multicolumn{3}{l}{ Perception of a perceived barrier } \\
\hline Not good & 53 & 48.2 \\
Good & 57 & 51.8 \\
\hline Perception of self-efficacy & & \\
\hline Not good & 18 & 16.4 \\
Good & 92 & 83.6 \\
\hline Family, social, and health workers support \\
\hline Not sufficient & 53 & 48 \\
Sufficient & 57 & 52 \\
\hline Patient compliance & & \\
\hline Not compliant & 58 & 52.7 \\
Compliant & 52 & 47.3 \\
\hline
\end{tabular}

Hypertension is a disease that can prevent and be prevented. Recently hypertension shows a high prevalence in the adult population (CDC, 2013). One of the most critical factors that play a role in blood pressure control is the patient's approval of care and diet. Patients who show low coverage for treatments that have uncontrolled high blood pressure and cause negativity arising from these complications are death (Wei et al., 2017). Therefore, it is essential to determine and consider the factors that affect patient compliance.

Under the statement of the Black and Hawks in Temang that age is one of the factors that influence blood pressure, the older a person is, the greater the risk of developing hypertension due to old age. The large arteries lose flexibility and become stiff because of that when the blood throbs forcefully to pass through blood vessels that are narrower than usual and cause an increase in blood pressure (Temang, 2013). It is consistent with the 2018 Riskesdas data, and hypertension occurs in the age group $31-44$ years $(31.6 \%$ ), ages $45-54$ years $(45.3 \%)$, ages $55-64$ years (55.2\%) (Kementerian Kesehatan Republik Indonesia, 2019a), it appears that the prevalence hypertension increases with age.

In this study, the results showed that hypertension sufferers with the highest sex are women (86.4\%). It is in line with Tarigan's results that women with hypertension are more numerous than men (53.7\%) (Tarigan, Lubis and Syarifah, 2018) and in line with Arnoldus, namely patients hypertension in women is higher at $60.5 \%$ compared to patients with hypertension in men (Arnoldus, 2019).

Based on the results of the chisquare test showed in Table 2, there is no relationship between age, sex, level of education, occupation, knowledge, attitudes, perceptions of perceived benefits, perceptions of perceived barriers, perceptions of self-efficacy ( $P$ Value>0.05). There is a relationship between factors of family support, social environment, and health workers with compliance of patients with hypertension $(\mathrm{OR}=2.461 ; \mathrm{Cl} 95 \% 1.140$ TO $5.310 ; \mathrm{P}$ Value $=0.034$ ).

Sociodemographic factors and individual characteristics that have been shown to influence adherence even though the mechanism is unclear is age, although the effect of age is not always the same in research. Several studies have shown a positive relationship between age levels and patient compliance. Younger patients tend to be more disobedient compared to older patients (Temang, 2013). The social demographic factors of age in Olowookere's research results show a significant relationship with adherence; the study showed that nonadherence was higher in young respondent and those with lower education (Olowookere et al., 2015). 
Table 2. The Correlation of Individual Perceptions, Modifying Factors, and the Likelihood of Action with Patient with Hypertension's Compliance

\begin{tabular}{|c|c|c|c|c|c|}
\hline \multirow{3}{*}{ Variable } & \multicolumn{4}{|c|}{ Patient compliance } & \multirow{3}{*}{ P Value } \\
\hline & \multicolumn{2}{|c|}{ Not compliant } & \multicolumn{2}{|c|}{ Compliant } & \\
\hline & $n$ & $\%$ & $n$ & $\%$ & \\
\hline \multicolumn{6}{|l|}{ Age } \\
\hline$\geq 45$ year & 43 & 49 & 45 & 51 & \multirow{2}{*}{0.166} \\
\hline$<44$ year & 15 & 68 & 7 & 32 & \\
\hline \multicolumn{6}{|l|}{ Sex } \\
\hline Male & 8 & 53 & 7 & 47 & \multirow{2}{*}{1} \\
\hline Female & 50 & 53 & 45 & 47 & \\
\hline \multicolumn{6}{|l|}{ Level of education } \\
\hline$\leq$ Junior high school & 41 & 55 & 34 & 45 & \multirow{2}{*}{0.696} \\
\hline > Junior high school & 17 & 49 & 18 & 51 & \\
\hline \multicolumn{6}{|l|}{ Job } \\
\hline Employed & 14 & 70 & 6 & 30 & \multirow{2}{*}{0.143} \\
\hline Unemployed & 44 & 49 & 46 & 51 & \\
\hline \multicolumn{6}{|l|}{ Knowledge } \\
\hline Not sufficient & 34 & 59 & 24 & 41 & \multirow{2}{*}{0.264} \\
\hline Sufficient & 24 & 46 & 28 & 54 & \\
\hline \multicolumn{6}{|l|}{ Attitude } \\
\hline Negative & 34 & 52 & 32 & 49 & \multirow{2}{*}{0.907} \\
\hline Positive & 24 & 55 & 20 & 46 & \\
\hline \multicolumn{6}{|c|}{ Perception of Perceived Benefits } \\
\hline Not good & 12 & 71 & 5 & 29 & \multirow{2}{*}{0.180} \\
\hline Good & 46 & 50 & 47 & 51 & \\
\hline \multicolumn{6}{|c|}{ Perception of Perceived Barrier } \\
\hline Not good & 32 & 60 & 21 & 40 & \multirow{2}{*}{0.174} \\
\hline Good & 26 & 46 & 31 & 54 & \\
\hline \multicolumn{6}{|c|}{ Perception of Self Efficacy } \\
\hline Not good & 13 & 72 & 5 & 28 & \multirow{2}{*}{0.120} \\
\hline Good & 45 & 49 & 47 & 51 & \\
\hline \multicolumn{6}{|c|}{ Family Support, Social Support, and Health Workers } \\
\hline Not sufficient & 34 & 64 & 19 & 36 & \multirow{2}{*}{0.034} \\
\hline Sufficient & 24 & 42 & 33 & 58 & \\
\hline
\end{tabular}

In contrast to the results of this study, there is no relationship between age and adherence, which is in line with the results of a study which shows no the relationship between age and adherence (Mathew et al., 2016), as well as the results of the study in 2013 there was no relationship between age and patient compliance with hypertension management (Temang, 2013).

Gender has no direct effect on adherence. It is interesting because research conducted in different places and with different populations can give different results. In this study, the results showed there was no relationship between sex with compliance; this is in line with the results of research by Mathew in Kerala, which showed no relationship between sex with adherence (Mathew et al., 2016), as well as the results of Temang's research In 2013 there was no relationship between sex and patient compliance with hypertension management, although there was no significant correlation in the value of the Odds Ratio (OR) of 0.65, which means that men had a 0.65 chance to be more obedient than women (Temang, 2013).

The level of education indirectly affects blood pressure. The level of education influences lifestyles such as smoking habits, alcohol drinking habits, and physical activity habits such as sports. The high risk of developing hypertension in low education may be caused by a lack of knowledge about health and the difficulty of receiving information provided by health workers so that it impacts on healthy behavior. Patients with a higher level of formal education tend to have better knowledge about hypertension and its management (Temang, 2013).

In this study, there was no significant relationship between education and hypertension patient compliance. The results of this study are 
consistent with the previous research, which states about education; there is no clear trend with compliance (Osamor, 2015). In contrast to the results of research conducted in 2015 stated, education shows a significant relationship with compliance (Olowookere et al., 2015). It is supported by the Temang research results, which show that there is a significant relationship between education and patient compliance with hypertension management, with an OR score of 7.1, which means that respondents with junior and senior high school education have a 7.1 chance to be more obedient compared to respondents with low education (Temang, 2013).

The results of the analysis of the relationship between the level of knowledge with adherence in this study found that there was no significant relationship between the level of knowledge with patient compliance; this is in line with the results of research by Temang; namely, there is no significant relationship between knowledge with patient compliance with hypertension management with OR 2, 52 then respondents with a high level of knowledge have a 2.52 times chance to be more obedient compared to respondents who have insufficient knowledge (Temang, 2013)

Patients' perceptions determine the response to their disease. Patients who get adequate information from health workers and believe in beneficial treatment, illness can have a severe impact, they are susceptible to disease, they can carry out prescribed treatments, and have a positive attitude towards treatment, showing better adherence against hypertension (Temang, 2013).

The results of the analysis of the relationship between perception of disease and treatment with adherence in this study found that there was no significant relationship between perception of disease and treatment of patient compliance. It is different from the results of research in 2013; namely, there was a significant relationship between perception of disease and treatment with patient compliance with hypertension management with OR 3.15, respondents who have an excellent perception have a 3.15 times chance to be more obedient compared to respondents who have a poor perception (Temang, 2013).

The results of this study indicate that there is a significant relationship ( $P$ Value $=0.034$ ) between family support, social support, and health workers with the compliance of patients with hypertension. This study is line with the result of other research that also proves that family support and social support are strongly associated with adherence to treatment of hypertension (Li, G., Hu, H.H., \& Aroo, 2015). Patients with good family support had better adherence compare to those with low-income family support (Olowookere et al., 2015). In southwest Nigeria, social support is strongly associated with hypertension treatment compliance in the community (Osamor, 2015). These findings emphasize the need to ensure family and social support at the start and continuation of antihypertensive therapy (Padhy et al., 2016).

In Indonesia, the results of research in 2016 showed that there was a supportive and healthy relationship between family support and patients with hypertension, which showed that family support contributed $61.8 \%$ to support patients with hypertension. Previous researches stated that there was a relationship between families related to diet in patients with hypertension (Yeni, Husna and Dachriyanus, 2016; Prihartono, Andarmoyo and Isroin, 2019). Other research stated there was a relationship between family support and taking medication in patients with hypertension (Arnoldus T, 2019). Good family support has a six times chance of implementing a good hypertension diet compared to lowincome family support (Tarigan, Lubis and Syarifah, 2018). Likewise, another study stated that there was a positive and significant relationship between family support and hypertension diet (Kusumawati, 2014). It is in line with the results of research by Temang; namely, there is a significant relationship between social support and patient compliance with hypertension management with OR 6.7 then respondents who have good social support have a 6.7 times chance to be more obedient compared to respondents who have poor social support (Temang, 2013). From the various research results above, it can be seen that one of the factors affecting 
hypertension patients is family and social support. It is because patients with relatively high elderly use large medicinal substances, parents who help others, namely family members, to remind them to take medicine and diet.

Family and social support are essential in supporting adherence to people with hypertension. Family attention can foster motivation for patients to be obedient. Health workers change the pattern of relationships to be equal to the patient, show empathy, want to listen, and explain correctly will affect compliance (Temang, 2013).

Chronic diseases, such as hypertension, require a lifetime of care. It is a challenge for patients and families to be able to maintain the budget for years of care. One way to increase motivation is through family support. Social support will increase awareness to use health services, which is one of the critical components that meet the requirements (Osamor, 2015).

Various studies have shown that antihypertension is a global problem that requires many solutions ( $\mathrm{Si}, 2012$; Desai and Choudhry, 2013). The study reported a decline rate of $52.7 \%$ among respondents. While in 2012, 32\%, and in 2015 it was approved that $39 \%$ of patients were not approved for therapy (Si, 2012; Olowookere et al., 2015). Furthermore, the results of research in the Kingdom of Saudi Arabia, the meeting was 35.1\% (Mahmoud, 2012). The difference in judgment is mainly by the various measurement methods agreed upon by these authors. But these varied results imply that what cannot be solved remains a problem that requires a solution

\section{CONCLUSION}

Based on the results of data analysis and research results, the conclusion obtained in this study is that there is a relationship between family support, social support, and support from health workers on hypertension patient compliance. Community health centers, as primary health care facilities, need to make efforts to improve hypertension patient compliance so that risk factors and hypertension complications can be reduced or prevented.

In order to improve compliance of patients with hypertension, it is necessary
(Kementerian Kesehatan Republik Indonesia, 2019b)to pursue a program of activities focused on health promotion activities not only for patients but also involving family and social members. Activities can include routine health checks, emphasizing healthy living behavior, carried out education or dissemination of information in the form of the development of information media both to patients and families related to hypertension.

\section{REFERENCES}

Arnoldus T, Y. (2019) Hubungan antara dukungan keluarga dengan kepatuhan minum obat pada penderita hipertensi di RSUD Dr. WZ Johannes Kupang NTT. Universitas Airlangga.

CDC, C. for D. C. and P. (2013) 'Centers for Disease Control and Prevention. National Diabetes Statistic Report:Estimates of Diabetes and Its Burden in the United States,2014', Reporteros Sin Fronteras, pp. 20092012. doi: $10.1177 / 1527154408322560$.

Desai, N. R. and Choudhry, N. K. (2013) 'Impediments to adherence to post myocardial infarction medications topical collection on new therapies for cardiovascular disease', Current Cardiology Reports, 15(1). doi: 10.1007/s11886-012-0322-6.

Forouzanfar, M. H. et al. (2016) 'Global, regional, and national comparative risk assessment of 79 behavioural, environmental and occupational, and metabolic risks or clusters of risks, 1990-2015: a systematic analysis for the Global Burden of Disease Study 2015', The Lancet, 388(10053), pp. 1659-1724. doi: 10.1016/S01406736(16)31679-8.

Kementerian Kesehatan Republik Indonesia (2014) 'Pusdatin Hipertensi', Infodatin, (Hipertensi), pp. 1-7. doi: 10.1177/109019817400200403.

Kementerian Kesehatan Republik Indonesia (2019a) 'Hipertensi Penyakit Paling Banyak Diidap Masyarakat', Kementerian Kesehatan RI. Sekretariat $r$ Jenderal. Rencana Strategis Kementerian Kesehatan Tahun Rencana Strategis Kementerian Kesehatan Tahun, p. 248. doi: 351.077 Ind $r$.

Kementerian Kesehatan Republik Indonesia (2019b) Laporan Nasional 
Riskesdas Tahun 2018. Jakarta.

Kusumawati, D. (2014) Hubungan pengetahuan dan dukungan keluarga dalam pengaturan diit hipertensi dengan kepatuhan diit penderita hipertensi di wilayah kerja Puskesmas Mojo Panggung Banyuwangi. Sebelas Maret Surakarta.

Li, G., Hu, H.H., \& Aroo, T. (2015) 'The association of family social support, depression, anxiety and self-efficacy with specific hypertension self-care behaviors in Chinese Local Community', Journal of Human Hypertension, 29(3), pp. 198-203.

Mahmoud, M. I. H. (2012) 'Compliance with treatment of patients with hypertension in Almadinah Almunawwarah: A community-based study', Journal of Taibah University Medical Sciences. Taibah University, 7(2), pp. 92-98. doi: 10.1016/j.jtumed.2012.11.004.

Mathew, J. et al. (2016) 'Non Compliance to Anti-Hypertensive Medications and Associated Factors- Community Based Cross Sectional Study from Kerala', Scholars Journal of Applied Medical Sciences, 4(6), pp. 1956-1959. doi: 10.21276/sjams.2016.4.6.18.

Mills, K. T. et al. (2016) 'Global disparities of hypertension prevalence and control', Circulation, 134(6), pp. 441-450.

doi:

10.1161/CIRCULATIONAHA.115.018912.

Olowookere, A. et al. (2015) 'Perceived family support and factors influencing medication adherence among hypertensive patients attending a Nigerian tertiary hospital', Annals of Tropical Medicine and Public Health, 8(6), pp. 241-245. doi: 10.4103/17556783.162668.

Osamor, P. E. (2015) 'Social support and management of hypertension in SouthWest Nigeria', Cardiovascular Journal of Africa, 26(1), pp. 29-33. doi: 10.5830/CVJA-2014-066.

Padhy, M. et al. (2016) 'Social Support and Adherence among Hypertensive Patients', Amity Journal of Healthcare Management AJHM ADMAA Amity Journal of Healthcare Management,
1(11), pp. 33-40.

Prihartono, W., Andarmoyo, S. and Isroin, L. (2019) 'Hubungan dukungan keluarga dengan kepatuhan pemenuhan diet pada penderita hipertensi', Health Sciences Journal, 3, p. 1. doi: 10.24269/hsj.v3i1.215.

$\mathrm{Si}$, B. (2012) 'Adherence and generic substitution among hypertensive patients in a specialist hospital', Global Advanced Research Journal of Medicine and Medical Sciences, 1(1), p. 8.

Tarigan, A. R., Lubis, Z. and Syarifah (2018) 'Pengaruh Pengetahuan, Sikap Dan Dukungan Keluarga Terhadap Diet Hipertensi Di Desa Hulu Kecamatan Pancur Batu Tahun 2016', Jurnal Kesehatan, 11(1), pp. 9-17. doi: 10.24252/kesehatan.v11i1.5107.

Temang, P. (2013) 'Analisis Faktor yang Berhubungan dengan Pasien TERHA MEN TENSI D ALAM K KONTEK KS ASUHA I KABUP ALISIS FA AKTOR- MEN'.

Wei, Y. C. et al. (2017) 'Assessing sex differences in the risk of cardiovascular disease and mortality per increment in systolic blood pressure: A systematic review and meta-analysis of follow-up studies in the United States', PLOS ONE, 12(1), pp. 1-15. doi: $10.1371 /$ journal.pone.0170218.

Whelton, P. K. et al. (2018) 2017 ACC/AHA/AAPA/ABC/ACPM/AGS/APhA / ASH/ASPC/NMA/PCNA guideline for the prevention, detection, evaluation, and management of high blood pressure in adults a report of the American College of Cardiology/American Heart Association Task Force on Clinical pr, Hypertension. doi: 10.1161/HYP.0000000000000065.

WHO (2013) 'World Health Day 2013 Measure Your Blood Pressure, Reduce Your Risk', (September 2011), pp. 1-2.

Yeni, F., Husna, M. and Dachriyanus, D. (2016) 'Dukungan Keluarga Memengaruhi Kepatuhan Pasien Hipertensi', Jurnal Keperawatan Indonesia, 19(3), pp. 137-144. doi: 10.7454/jki.v19i3.471. 